REPORT NO. 5

\title{
DETERMINATION OF THE QUANTITY AND LOCATIONS OF THE PLUTONIUM RETAINED IN THE CIMARRON FUEL PLANT SYSTEMS
}

This report is prepared and submitted as a Task 2

Requirement in accordance with Contract

DE-AC06-83RL10382

U.S. Department of Energy

Richland Operations Office

P. O. Box 550

Richland, Washington 99352 


\section{DISCLAIMER}

Portions of this document may be illegible in electronic image products. Images are produced from the best available original document. 
REPORT NO. 5

DETERMINATION OF THE QUANTITY AND LOCATIONS OF THE PLUTONIUM RETAINED IN THE CIMARRON FUEL PLANT SYSTEMS

This report is prepared and submitted as a Task 2 Requirement in accordance with Contract DE-AC06-83RL10382

$$
\text { to the }
$$

U. S. Department of Energy

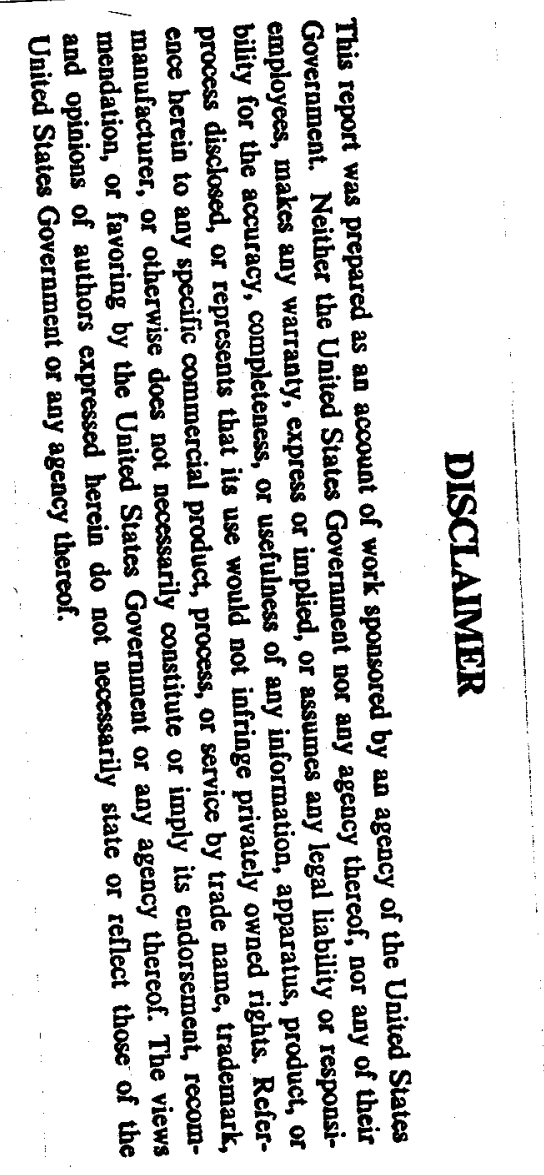

Richland Operations office

P. O. Box 550

Richland, Washington

Prepared By

Sequoyah Fuels Corporation

P. O. Box 25861

Oklahoma city, oklahoma 73125 


\section{TABLE OF CONTENTS}

PAGE

1 EXECUTIVE SUMMARY 1

2 INTRODUCTION 3

3 BACKGROUND 6

4 STANDBY INVENTORY (1976) 12

5 FINAL MEASUREMENTS 23

6 AUDIT TEAM 36

7 COMPARISON OF MEASUREMENT DATA

8 SUMMARY AND CONCLUSIONS 


\subsection{EXECUTIVE SUMMARY}

In late 1975, Sequoyah Fuels Corporation (SFC)* announced its intention to suspend operations of its cimarron Plutonium Fuel Fabrication Facility and to place the Facility in a standby status pending development of further activities. SFC, using non-destructive assay (NDA) measurment techniques, measured the residual plutonium held-up in the plant process equipment to establish a standby inventory hold-up baseline. The NRC's office of Inspection and Enforcement assembled a team of various government experts that independently measured the plutonium hold-up, using NDA techniques.

In 1979, SFC elected to decontaminate the plutonium operation for purposes of decommissioning the site and terminating the NRC Iicense. Care was taken throughout the

* SFC became the owner of the cimarron Facility in 1983, when Kerr-McGee Nuclear Corporation was divided into SFC and Quivira Mining corporation. 
decontamination program to accurately measure the plutonium content and identify the origin of over 28,000 individual packages of contaminated equipment removed from the plant. The final measurement data for these smaller packages were compared with the results of the 1976 baseline measurement program.

This report compares the results of the 1976 baseline inventory data and the NRC team's data with the final measurement data obtained during the decontamination and decommissioning ( $D \& D)$ effort.

The summary of the three independent measurement programs is shown in Table 1 .

TABLE 1

SUMMARY

GRAMS OF PLUTONIUM

Inventory Limit-of-

Measurement Lower Limit Upper Limit Error (1)

$\begin{array}{lcccc}\text { Baseline } & 10,818 & 7,843 & 13,793 & \pm 2,975 \\ \text { NRC Team } & 7,960 & 4,850 & 11,810 & +3,850 \\ & & & & -3,110 \\ \text { Final D\&D } & 9,210 & 8,796 & 9,624 & \pm 414\end{array}$

(1) 958 Confidence Level 


\subsection{INTRODUCTION}

Sequoyah Fuels Corporation's (SFC) Cimarron Plutonium Fuel Fabrication Facility was constructed in 1969 for the primary purpose of manufacturing plutonium-uranium mixed oxide fuel pins. The process consisted of coprecipitating plutonium and uranyl nitrate solutions into mixed oxide, pressing the mixed oxide into fuel pellets, and loading the finished pellets into fuel rods. The process also included complete scrap dissolution and recycle capabilities as well as necessary laboratory facilities to support production activities.

During the period 1970 through 1975 , more than two million grams of plutonium were received in the form of plutonium nitrate and were converted into fuel pellets. The pellets were used in various governmental research and development programs, including the zero Power Plutonium Reactor and Fast Flux Test Facility programs.

Since the plant equipment included more than $30,000 \mathrm{ft}^{2}$ of glovebox process area and almost one mile of process piping, methods were developed by SFC for conducting 
in-place non-destructive assay (NDA) measurement programs to determine the inventory of plutonium hold-up in the process equipment. The methods developed by SFC during the 1973-1975 period for measuring inventory hold-up were used in early 1976 to establish a baseline inventory for purposes of placing the facility on standby status.

Shortly thereafter, NRC's office of Inspection and Enforcement assembled a team of experts from various government laboratories to verify SFC's measurements. The NRC Audit team used independent instrumentation and developed specific techniques and procedures for their in-place NDA of the Plutonium Fuel Fabrication Facility.

The independent audit team was directed by W. - A. Higenbotham of the Brookhaven National Laboratory. The members and their professional affiliations were:

Don M. Sikes - ERDA, Division of Safeguards and Security Martin S. Zuker - Brookhaven National Laboratory David M. Gordon - Brookhaven National Laboratory Richard Machnowski - Brookhaven National Laboratory James W. Tape - Los Alamos Scientific Laboratory Michael L. Evans - Los Alamos Scientific Laboratory Norbert Ensslin - Los Alamos Scientific Laboratory Richard Siebelist - Los Alamos Scientific Laboratory 
The results of the audit team's work were summarized by $\mathrm{J}$. W. Tape in what has since become known as the "Tape Report".

Given the state of the art in early 1976, the experimental methods used, and the inherent difficulties of the task, the "Tape Report's" conclusion was that the results of the two independent measurements were in substantial agreement.

In 1979, SFC elected to decommission the plutonium fuel plant. Measurement data were collected throughout the subsequent decommissioning program for correlation and comparison with the data from the two measurement programs conducted in 1976 .

This report discusses the methods used and the results obtained. It also provides detailed summaries of plant, room, and specific equipment measurements. 


\subsection{BACKGROUND}

\subsection{PLANT LAYOUT}

The process area, shown in Figure 1 , consisted of separate rooms for the major activities and was separate from the laboratory and administrative areas of the plant. Figures 2 through 8 depict each primary process area and the location of specific equipment in each of the areas. The primary process areas were: .

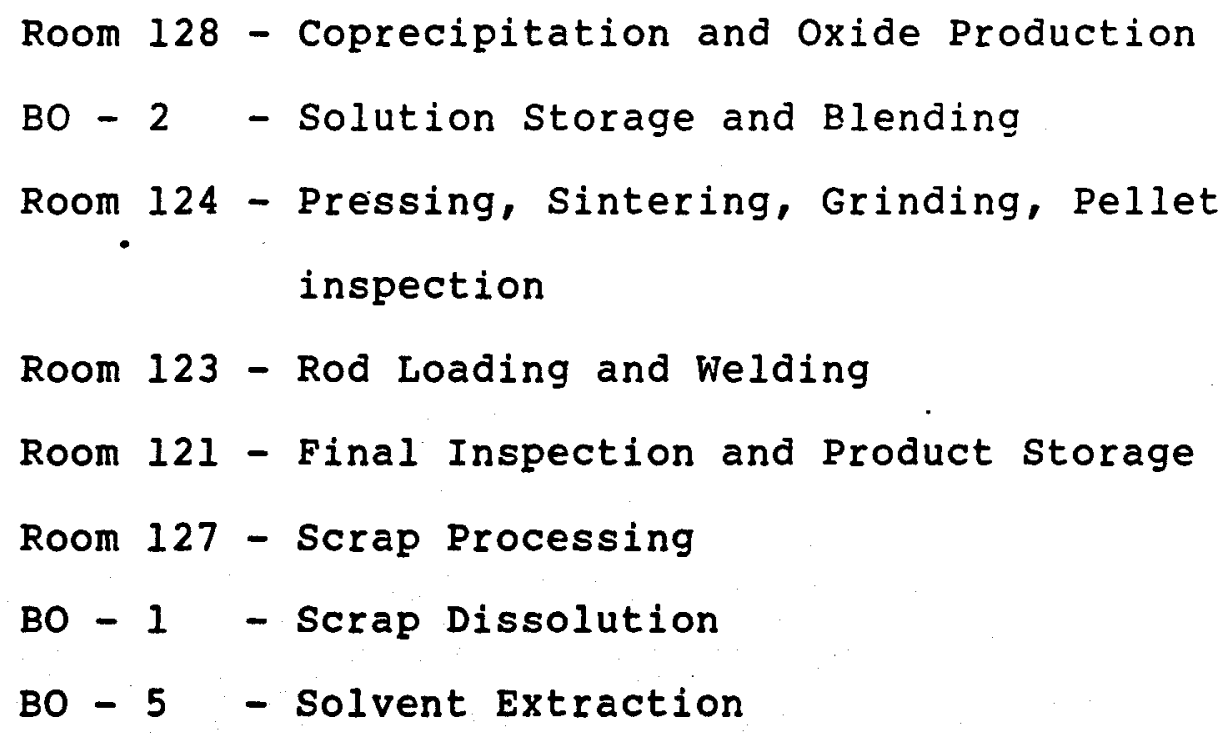

All process equipment was totally enclosed in forty-one gloveboxes of various sizes and dimensions. The solvent extraction glovebox, for example, was three stories tall and took up three walls of a room as shown in Figure 8 . 


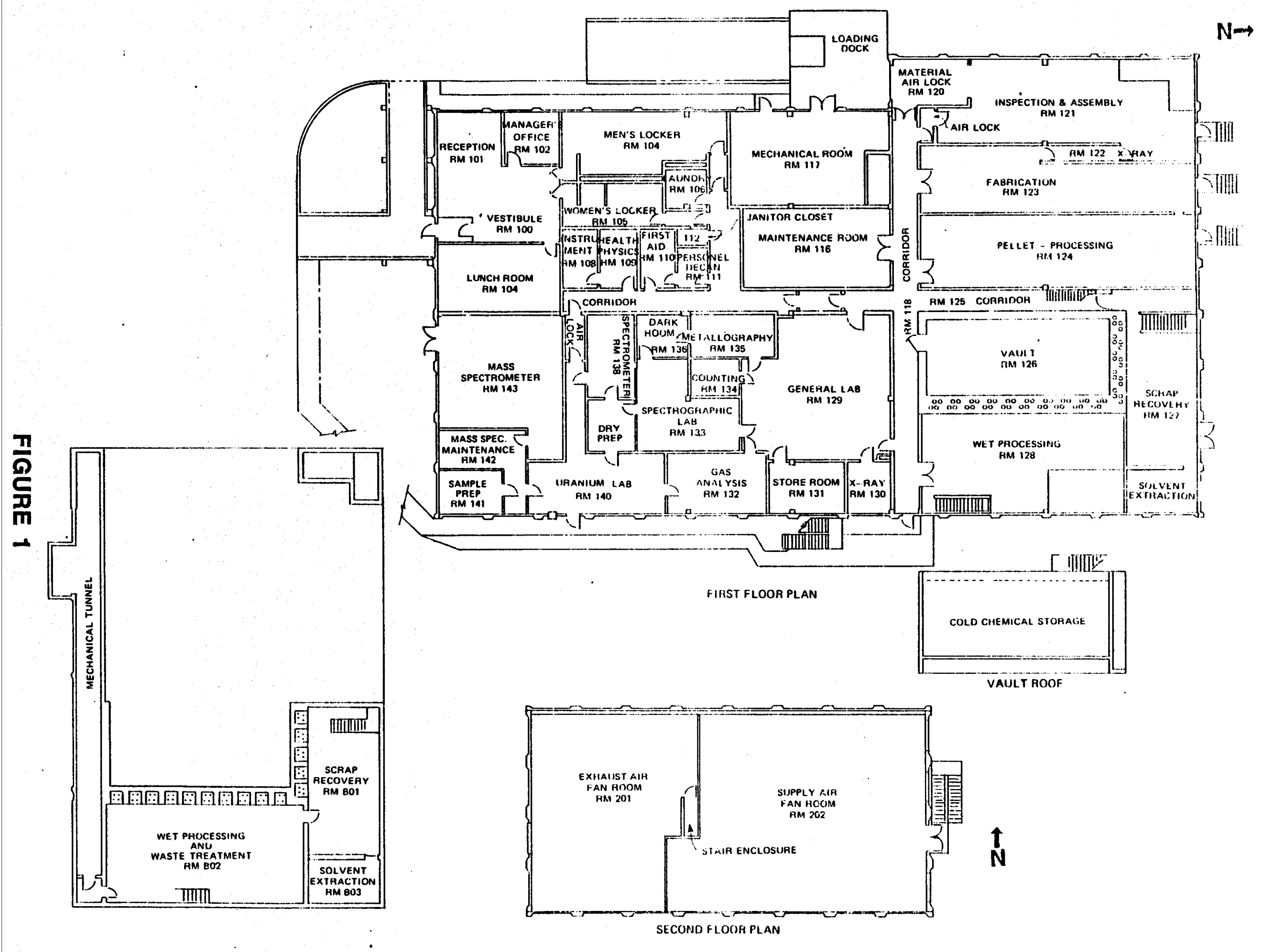


WET PROCESS

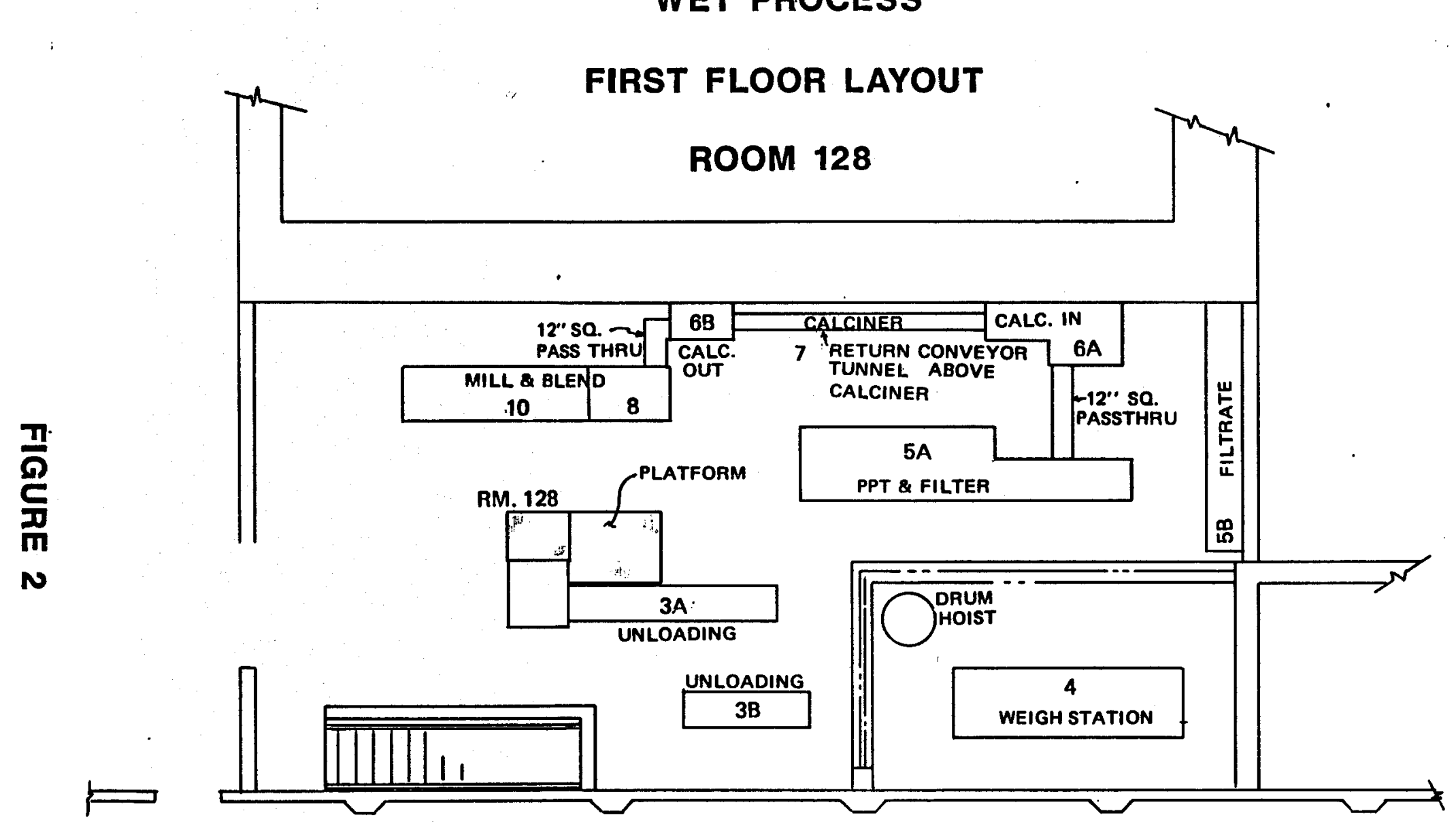


WET PROCESS

BASEMENT LAYOUT

ROOM BO-2

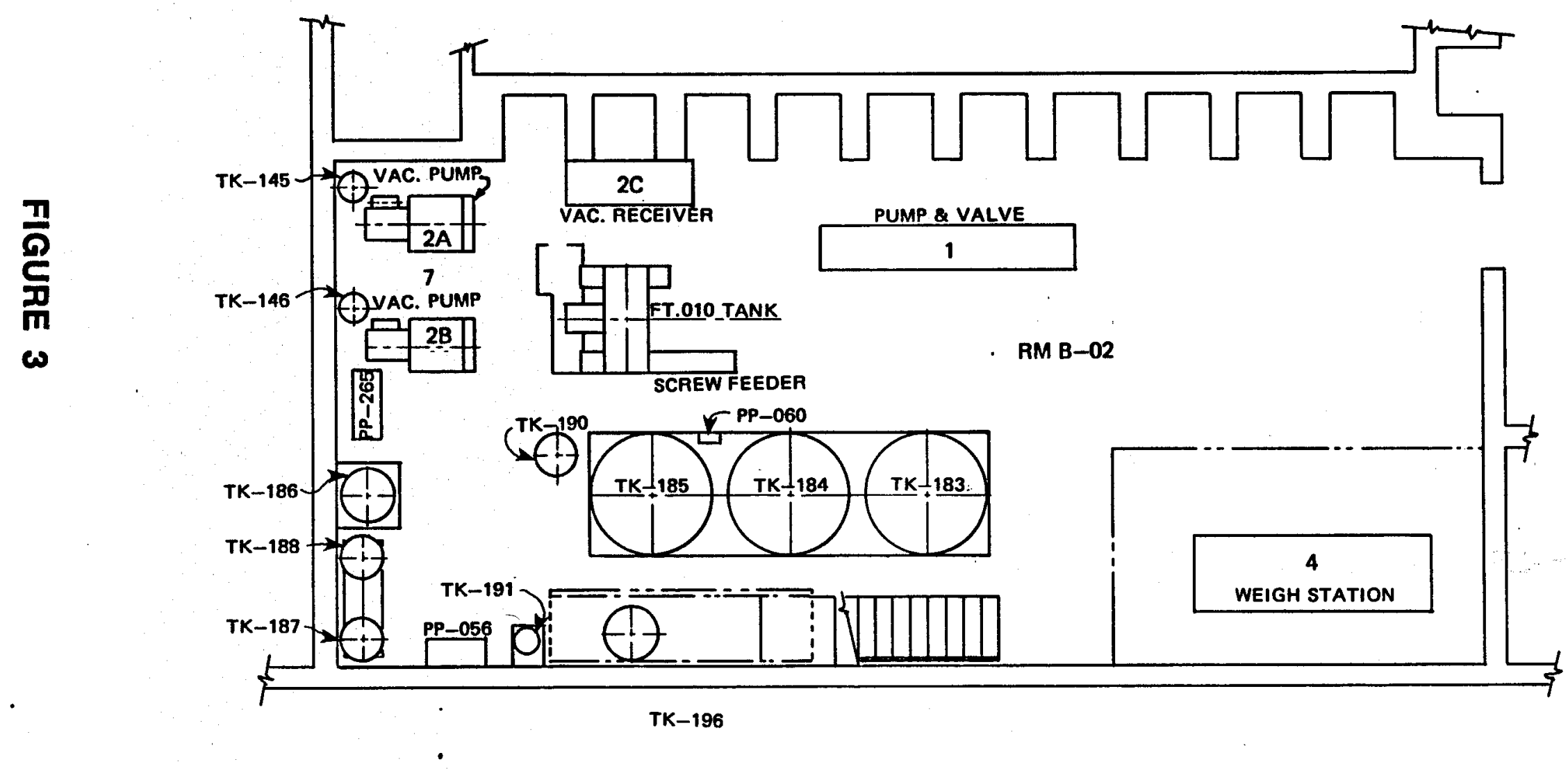


DRY PROCESS LAYOUT

ROOM 124

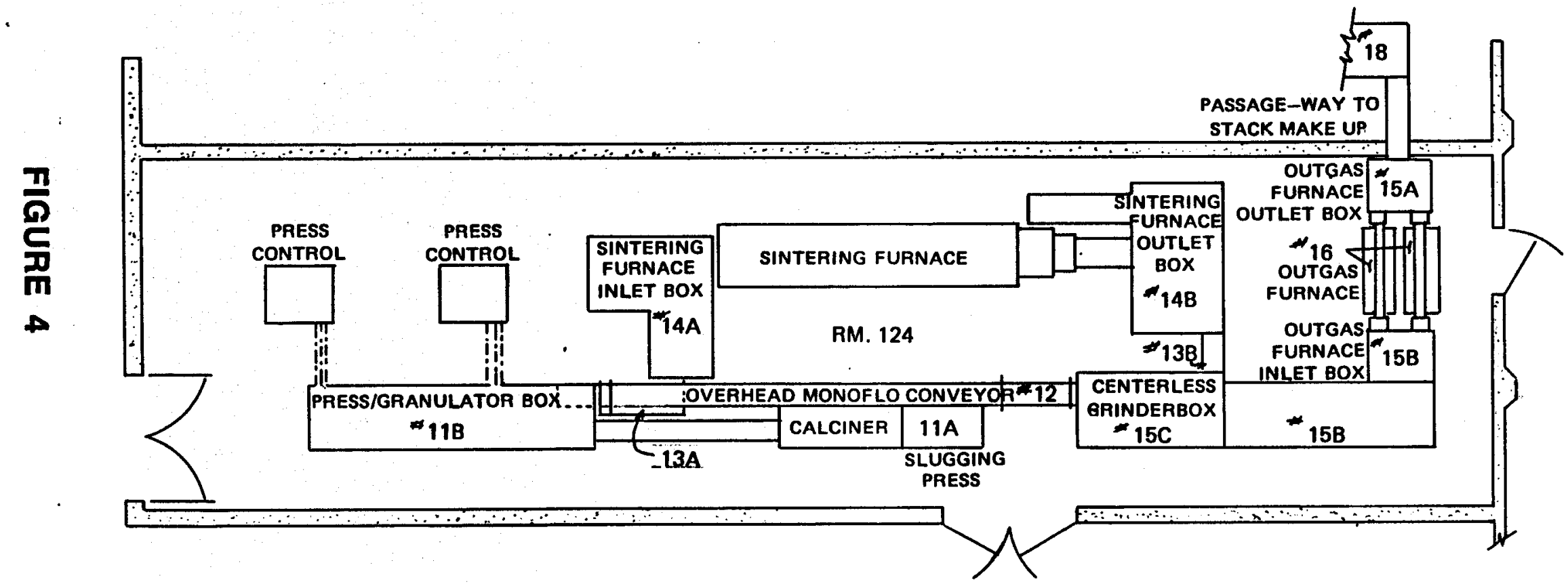




\section{FABRICATION LAYOUT}

ROOM 123

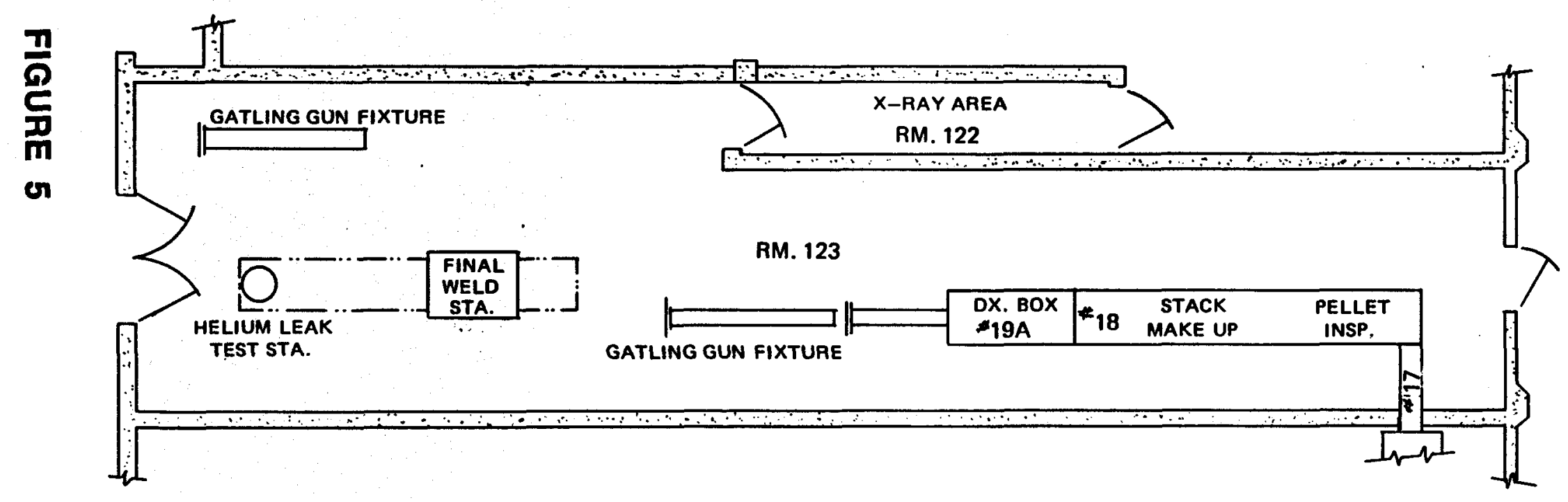




\section{CLEANING AND FINAL INSPECTION}

\section{ROOM 121}

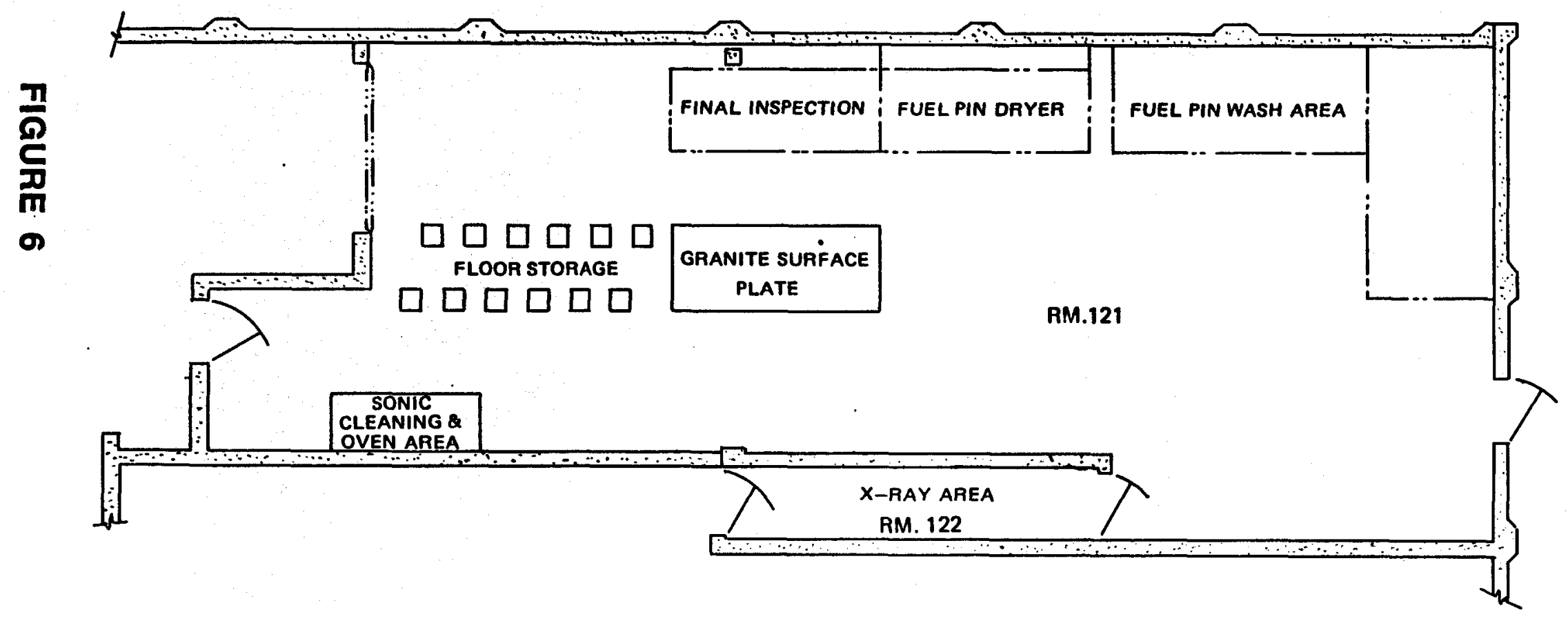


SCRAP FACILITY

\section{FIRST FLOOR LAYOUT}

ROOM 127

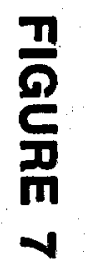

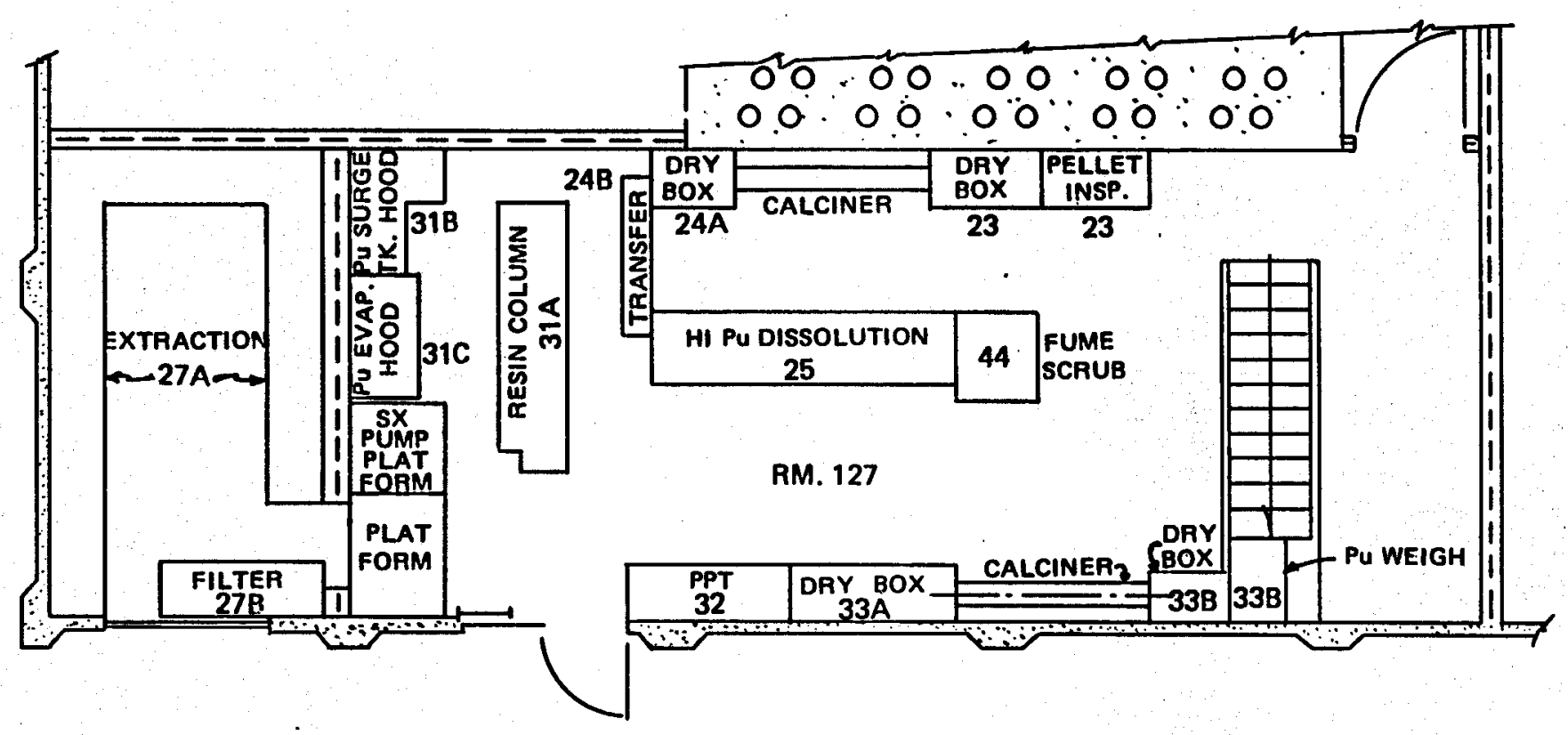




\section{SCRAP FACILITY}

\section{BASEMENT LAYOUT}

ROOM BO-1

$\frac{1}{0}$

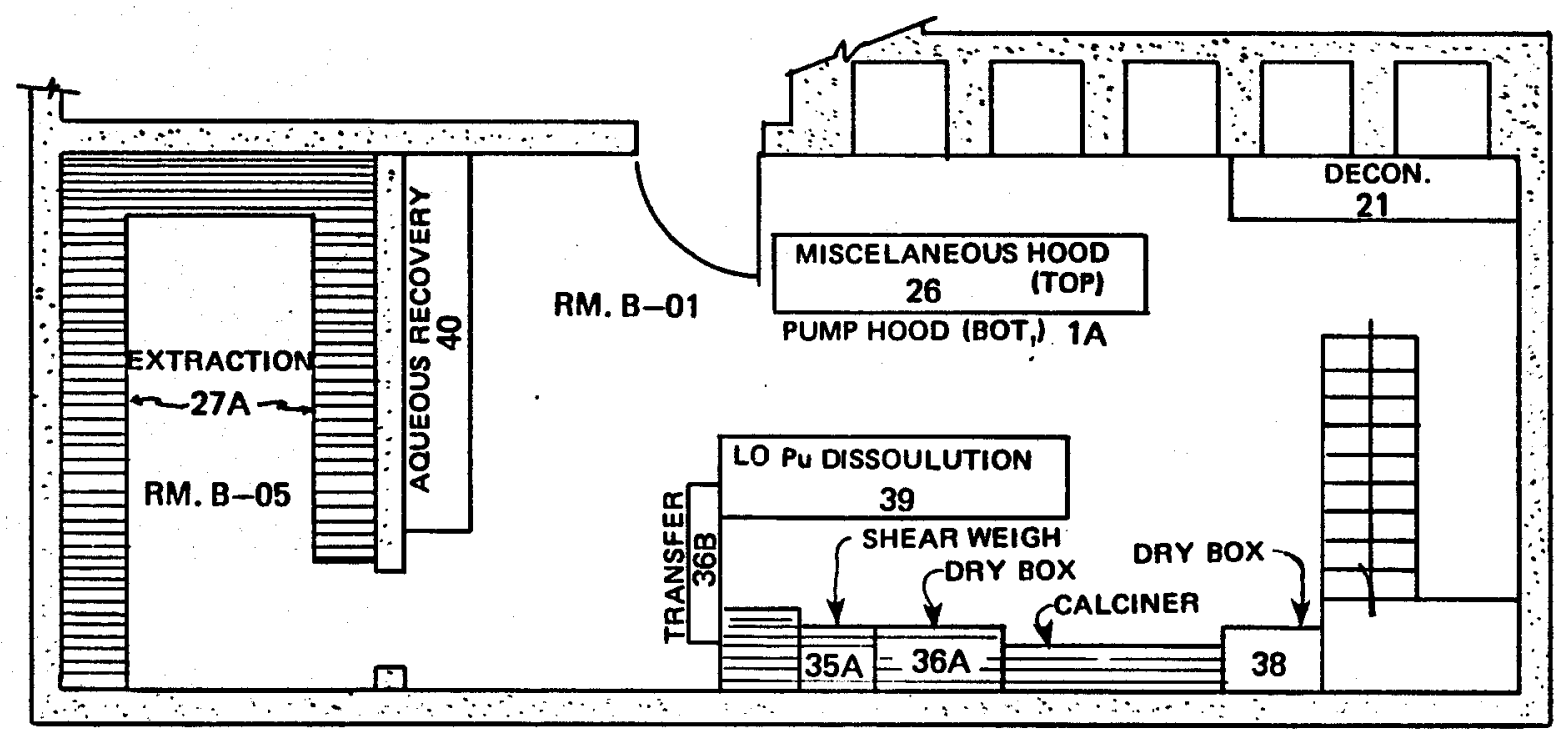


The gloveboxes represented approximately $30,000 \mathrm{ft}^{2}$ of surface area. In addition, approximately 4,500 linear feet of various piping connected the processes, ventilation ducts, solution holding tanks, and other process related items throughout the plant.

\subsection{NDA PROGRAM}

Sequoyah Fuels' NDA Program was developed over a two year period during production operations. This program generally involved a thorough clean-out of visual materials from gloveboxes, acid rinsing of pipes, and, in some areas, filter changes. Original1y, acid washing of glovebox surfaces was accomplished prior to measurement; however, routine acid washing proved to be detrimental to the equipment. Removal of all containerized plutonium materials and a good thorough sweep down of the gloveboxes proved to be an acceptable method without degrading the confidence in the data. 
The procedure was to establish a fixed set of representative measurement points to be measured each time. an inventory was made and to extrapolate the measurements over areas not measured. For example, the full length of a forty foot long pipe was not measured. One accessible spot was measured and the data extrapolated over the forty feet.

Report \#4 in this series, Non-Destructive Assay (NDA) Techniques and Procedures, identifies the equipment, techniques and procedures used to measure and calculate the quantities of plutonium heldup in the system for both semimonthly inventory purposes and SFC's early 1976 standby inventory measurement.

Figure 9 shows a typical arrangement of assay equipment during an NDA measurement of a glovebox.

\subsection{STANDARDS DEVELOPMENT}

Calibration standards traceable to the National Bureau of Standards with isotopic distribution similar to the plutonium materials in the plant were not available from any known source. 


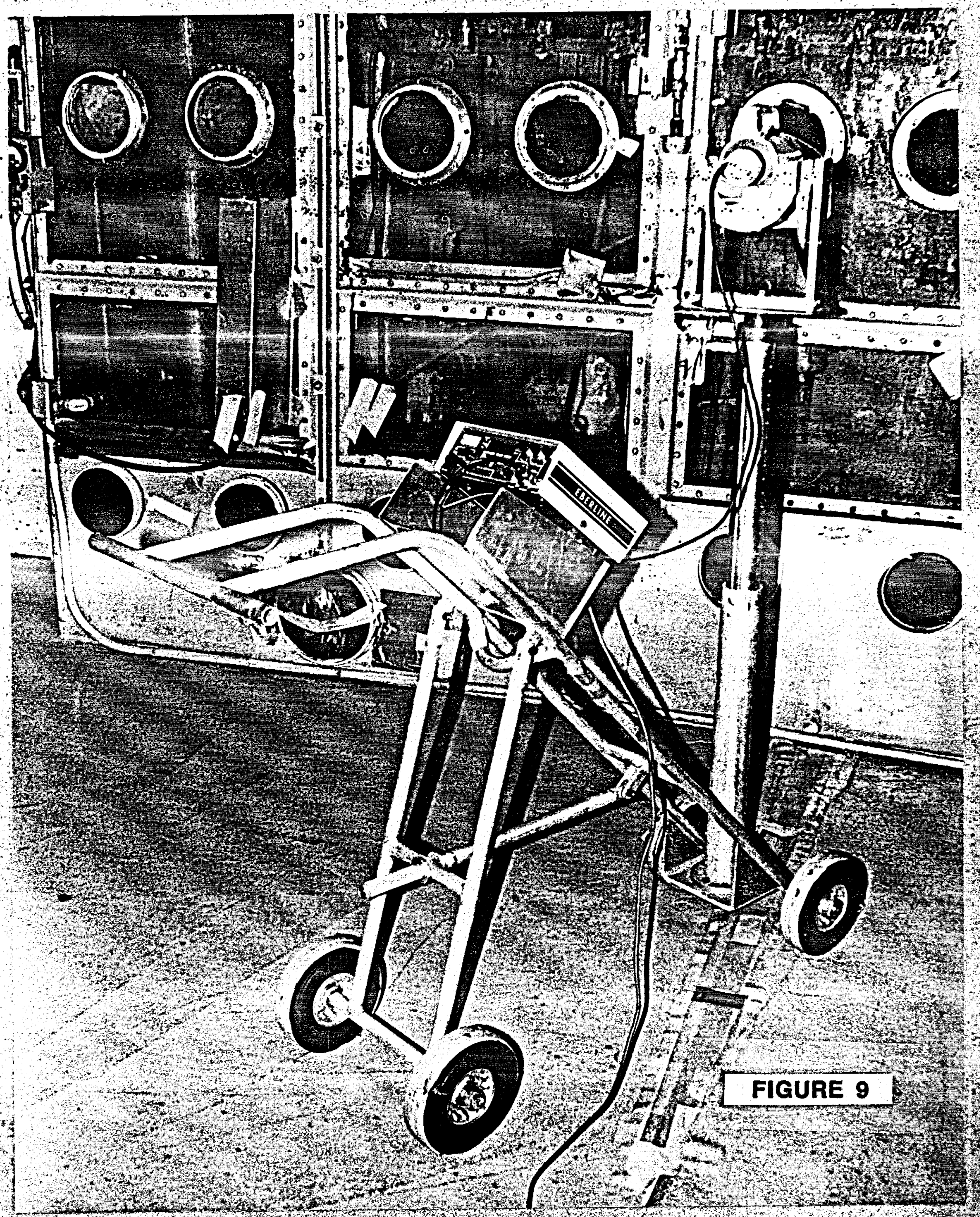


To calibrate and maintain confidence in the instrumentation used in the measurement program a set of calibration standards was developed by SFC from production materials. These standards were prepared as follows:

- A specified quantity of mixed oxide 11.936 grams Pu) was mixed with a clear acrylic paint resin.

- The resin mixture was spread on paper towels $(10-1 / 2 " x+12)$ in a thin layer as uniformly as possible.

- The saturated towels were dried and encapsulated in 0.012 " thick plastic packets.

A group of 13 packets was made; however, two were discarded because they contained small areas of highly concentrated activity (hot spots). The remaining 11 packets were then compared to Brookhaven National Laboratory and Los Alamos Scientific Laboratory standards and were determined appropriate for use.

During the NRC audit team's preparation for independently measuring the hold-up inventory, SFC's 
standard packets were measured by the team. The results of both Sequoyah Fuel's measurements and the audit team's measurements are shown on Table 11. Except for $K-M \# 7$, the values determined by the audit team were within \pm 108 of Sequoyah Fuel's values. As the audit team noted in their report, local nonuniformities in the distribution of $\mathrm{Pu}$ within the packet could lead to large errors in the calibration count rate if the sources were viewed at close range. However, viewing the sources at greater distances tended to average out the non-uniformities and to make the calibration count less sensitive to the exact positioning of sources relative to the detector.

Additionally, the audit team did not correct for selfattenuation of the sources. Any self-attenuation would reduce the observed count rate and measured mass which would have brought the observed results into even better agreement. 
TABLE 2

STANDARDS EVALUATION

SFC Value

Packet Number

1

3

$4 *$

5 *

6

$7 * *$

8

9

10

12

13
(Grams Pu)

1.934

1.937

1.944

1.944

1.932

1.932

1.930

1.938

1.932

1.928

1.940

1.939

1.941
Audit Team Value (Grams Pu)

$1.80 \pm 0.15$

$1.82 \pm 0.15$

$1.88 \pm 0.15$

$1.88 \pm 0.15$

$1.89 \pm 0.15$

$1.88 \pm 0.15$

$2.03 \pm 0.16$

$1.58 \pm 0.13$

$1.85 \pm 0.15$

$1.84 \pm 0.15$

$1.74 \pm 0.14$

$1.98 \pm 0.16$

$1.75 \pm 0.14$

* Measured Twice

* Number 7 was not used for calibration purposes. 


\subsection{STAND-BY INVENTORY (1976)}

\subsection{PREPARATION}

In preparation for placing the Facility on standby status, steps were taken to recover plutonium heldup in the process equipment. By March of 1976, all gloveboxes and pipes had been manually cleaned, all pipes had been flushed with acid, all glovebox filters had been replaced, all gloves had been removed from the gloveboxes, and all gloveports had been sealed with plastic covers. The remaining holdup plutonium was not accessible without removing the equipment as the plutonium was spread out in a very thin layer over the inner surfaces of the boxes, pipes and equipment or was retained in small amounts in pockets or crevices.

\subsection{METHODOLOGY}

The equipment, methods, and calculations employed for the in-place measurements are provided in detail in Report No. 4, Non-Destructive Assay (NDA) Techniques and Procedures, of this series. 
The in-place non-destructive assay measurement program was difficult because of several design features of the plant. As shown in Figures 2 through 8 , the process rooms were relatively small and allowed only enough room for technicians to operate the equipment. Additionally, most of the gloveboxes within each room were joined by a series of pass-through tunnels. These features prevented isolation of the item or area being measured; therefore, background radiation from adjacent equipment was present.

During the 1973-1975 development period, SFC demonstrated that the setup of the equipment could be consistently reproduced, the influence of background could be adequately shielded and the sensitivity of the instrumentation could be maintained. Thus, when the plant was placed on standby, SFC's NDA measurement program had been employed for some time, and confidence in the data was well established.

\subsection{Inventory Measurement}

The 1976 inventory measurements conducted by SFC are shown in Tables 3 through 11 . 
TABLE 3

1976 IN-PLACE INVENTORY

ROOM - 128 COPRECIPITATION AND OXIDE PRODUCTION

Box 8 and 10
Box 8 Filter
Box 10 Filter
Box 6B
Tunnel $(10-6 \mathrm{~B})$
Tunnel $(6 \mathrm{~B}-6 \mathrm{~A})$
Calciner
Box 6A
Box 6A Filter
Box 5B
Tunne1 (5A-6A)
Box 5A
Box 3A
Box 3B
Box 3B Filter
Ducts
TOTAL ROOM 128
LIMIT-OF-ERROR

Mill and Blend

Grams PIutonium

Box 8 and 10

Mill and Blend

241

Box 8 Filter

Calciner out (oxide)

5

Calciner Out (Oxide)

Box 6B

Tunnel (10-6B)

Tunnel (6B-6A)

47

Calciner In (ADU)

146

Filtrate

3
78

Precipitation \& Filter

2

Nitrate Solution Unloading

176

Nitrate Solution Unloading

32

28

$7 \overline{9}$

861

$\pm 237$ 
TABLE 4

1976 IN-PLACE INVENTORY

ROOM BO-2 SOLUTION STORAGE AND BLENDING

Grams Plutonium

Box 1
Tanks 145-146
BOX 2C
BOx 2A-2B
Wall Storage Tanks (40)
DP Cells
Box 4
Piping
TOTAL BO-2
LIMIT-OF-ERROR

Storage Tank Pumps 58

Vacuum receiver tanks Vacuum Receiver

Vacuum Pumps

72

12

Solution Storage

6

Tank level indicators

292

Solution Weigh station

220

643

393

1,696

$\pm 358$ 
TABLE 5

1976 IN-PLACE INVENTORY

ROOM 124 - PRESSING, SINTERING, GRINDING

Grams Plutonium

Box 11B.

Pressing and Granulating

382

Box 11B Filter

10

Calciner

Tunnel

BoX IIA

Box 11A Filter

BoX 12

Box 14A

Box 14B

Box 15C

Box 15C Filter

Box 15B

Box 15B Filter

Box 15A

Box 15A Filter

BoX 16

Box 13A

Box 13B

Boat return

Slugging Press Box

65

36

557

Overhead tunnel

Sintering Furnace Inlet

39

Sintering Furnace Outlet

109

Centerless Grinder

43

283

Outgas Furnace Inlet

Outgas Furnace outlet

50

Outgas Furnace

Press Trollys

Press Trollys

Filter

Duct

Portable Powder Carts (3)

Harper Furnace

203

TOTAL ROOM 124

1,995

LIMIT-OF-ERROR 


\section{TABLE 6 \\ 1976 IN-PLACE. INVENTORY \\ ROOM 123 - ROD LOADING AND WELDING}

Grams Plutonium

Box 17

Box 18

Box 18 Filter

Duct

TOTAL ROOM 123

LIMIT-OF-ERROR
Tunnel from 15A to Pellet storage 1 Stack Make-Up

36

1

38

$\pm 10$ 


\section{TABLE 7}

1976 IN-PLACE INVENTORY

ROOM 116 - MAINTENANCE

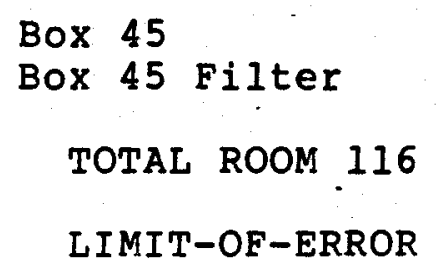

Grams Plutonium

Maintenance Glovebox

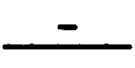

18

$\pm 5$ 
TABLE 8

1976 IN-PLACE INVENTORY

ROOM 127 - SCRAP PROCESSING

Grams Plutonium

Box 23

Pellet Inspection

106

Box 23 Filter

26

South Calciner

162

Tunnel South Calciner

Box 24A

Box 25

Box 25 Filter

Calciner exit box

30

23

Dissolution

Box 44

Fume Scrub

217

14

Box 44 Filter

Box $31 \mathrm{~A}$

Resin Column

48

Box 31B

Surge Tank

301

Box 31C

Evaporation Hood

167

Box 31B:31C

Precipitation

39

Box 32

Box 32 Filter

Precipitation

31

Box 33A

N. Calciner Entrance

30

Box 33A Filter

Box 33B

Box 33B Filter

Tunnel (24A-25)

N. Calciner Exit

North Calciner

$R$ Tunnel Calciner

2 Portable I-X

Duct

Tank Farm

72

TOTAL ROOM 127

1,494

LIMIT-OF-ERROR 
TABLE 9

1976 IN-PLACE INVENTORY

ROOM BO-1 SCRAP TREATMENT

\section{Grams Plutonium}

$\begin{array}{ll}\text { BoX } & 40 \\ \text { BoX } & 39 \\ \text { Box } & 26 \\ \text { BoX } & 1 A \\ \text { Box } 21\end{array}$

Tunnel (36-39)

Box 36A

Box 36 Filter

Box 38

Tunnel (36-38)

Calciner

Aqueous Recovery

Dissolution

Washables

Liquid transfer

Decon Dissolver

HEPA Filter Treatment

158

140

90

116

HEPA Filter Treatment

83

9

14

7

55

2

17

17

Duct

898

Wall Storage Tanks (20)

447

DP Cells

Piping

1,071

TOTAL ROOM BO-1

3,124

LIMIT-OF-ERROR

$\pm 565$ 


\begin{abstract}
TABLE 10
1976 IN-PLACE INVENTORY

ROOM BO-5 SOLVENT EXTRACTION
\end{abstract}

Grams Plutonium

Box 27A

1,592

LIMIT-OF-ERROR $\pm 438$ 
TABLE 11

\title{
1976 IN-PLACE INVENTORY \\ SUMMARY - ALL INVENTORY
}

Grams Plutonium

\author{
Room $128^{\circ}$ Coprecipitation \& Oxide Production \\ Room BO-2 Solution storage \& Blending \\ Room 124 Pressing, Sintering, Grinding \\ Room 123 Rod Loading \& Welding \\ Room 116. Maintenance \\ Room BO-1 Scrap Treatment \\ Room 127 Scrap Processing \\ Room BO-5 Solvent Extraction \\ TOTAL \\ LIMIT-OF-ERROR
}

1,995

3,124

1,494

1,592

10,818

$\pm 2,975$ 


\subsection{FINAL MEASUREMENT}

\section{I METHODOLOGY}

SFC elected to decontaminate the plutonium facility by cutting the process equipment into small pieces (i.e., less than 15" by 15") which could be packaged into 55-gallon drums for shipment to an off-site disposal area. The small pieces were counted with a Ludlum 2500 unit with a 2" $x 2^{\prime \prime}$ NaI detector which was set-up and calibrated to view each item.

In total, 28,357 packages were measured. Care was taken during the decontamination activities to segregate and document the origin of each piece for correlation of the early 1976 baseline measurement with the more accurate measurements of the 28,357 packages.

Several operational and administrative circumstances precluded correlations for all cases. First, some decontamination operations could not be conducted in a manner that allowed precisely assigning 
recovered plutonium to the original location. For example, a special large glovebox was modified to contain a plasma arc cutting unit used to cut equipment, including entire gloveboxes. Small portions of contaminated material (from the cutting operations) being cut up in this special glovebox lost identity and could not be assigned to the source box. Similarly, plutonium contained in pipes which may have crossed through rooms and airborne particulates trapped in absolute filters during cut-up activities could not be precisely assigned to a specific location.

Second, the period between the 1976 baseline measurements and the completion of the decontamination activity measurements was some 10 years. Over this period, administrative and personnel changes occurred; consequently, some individuals who had personal knowledge about various procedures and activities and who developed the raw data were not available to aid in the interpretation or explanation of questions about specific operations. 
In Tables 12 through 21 , the data from the two sets of measurements are provided and reflect the above limitations.

of particular note is the apparent transposition of the 1976 data for the wall storage tank measurements in Rooms $\mathrm{BO}-1$ and $\mathrm{BO}-2$. The final measurements indicate the earlier data were either recorded inaccurately or mislabeled during the 1976 inventory period.

Grams Plutonium

\begin{tabular}{cc} 
Grams Plutonium \\
\hline 1976 & Final \\
Inventory & Measurement
\end{tabular}

$\begin{array}{llllr}\text { BO-I Wall Tanks }(20) & 898 & 288 \\ \text { BO-2 Wall Tanks }(40) & 292 & 1,045\end{array}$

The audit team estimated the total plutonium for all 60 storage tanks and did not distinguish the 20 tanks in BO-l from the 40 tanks in BO-2; therefore only SFC data are available for review. That the data were mislabeled is strongly supported by the fact that the BO-2 tanks were used to store concentrated production solution, whereas the BO-1 tanks were used to store waste solution. 
TABLE 12

ROOM 128 COPRECIPITATION AND OXIDE PRODUCTION

Grams Plutonium

1976

Inventory

Box 8

Box 8 Filter

Box 10 Filter

Box 6B

Tunnel $(10-6 B)$

Tunnel $(6 A-6 B)$

Calciner

Box 6A

Box 6A Filter

Box 5B

Tunnel $(5 A-6 A)$

Box 5A

Box 3A

Box 3B

Box 3B Filter

Ducts

Tank 63

Cement Box

Box 27C

Not Assigned

TOTAL ROOM 128

LIMIT-OF-ERROR
Mill \& Blend

Calciner out

Calciner In

Filtrate

Precip. \& Filter

Nitrate Unloading

Nitrate Unloading
241

5

4

21

5
4

37

146

3

78

2

176

32

28

79

79

$-$

-

-

$=$

861

$\pm 237$
Final

Measurement

153

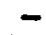

$-$

62

4

25

18

157

$2 \overline{5}$

161

29

23

2

-

1

33

733

$\pm 135$

3,201

NUMBER OF PACKAGES MEASURED

For contamination control purposes, the cleaning and cut up operations on powder boxes $8-10$ were performed with the exhaust air passing through the calciner tube into box $6 \mathrm{~A}$; therefore, the comparison of the 1976 value(s) with the final value can only be compared as a group (Box $8-10,6 B$, $6 \mathrm{~A}$, and calciner and tunnels) rather than individually. 


\section{ROOM BO-2 SOLUTION STORAGE AND BLENDING}

Grams Plutonium

Inventory

Box 1

Tanks 145-146

Box 2C

Box 2A-2B

Wall Storage Tanks DP Cells

Box 4

Piping

Tank 195

Tank 196
Storage Tank Pumps

Vacuum Receiver Tanks

Vacuum Receiver Box

Vacuum Pumps

Solution storage (40)

Tank Level Indicators

Solution Weigh scales

Flocculation Tanks

Not Assigned

Wash Pumps

Cubicles \& Floor

Process Pipe

TOTAL ROOM BO-2

LIMIT-OF-ERROR

1976

Final

Measurement

137

294

23

36

1,045

177

409

643

393

$\begin{array}{ll}- & 46\end{array}$

- 62

- 1

$\begin{array}{ll}- & 18\end{array}$

-

- 4

$-$

1,696

2,253

$\pm 466$

$\pm 268$

NUMBER OF PACKAGES MEASURED

7,855

The shielding involved with the raschig ring and liquid filled vacuum receiver tanks \#145 and \#146 resulted in a poor 1976 inventory measurement.

It appears that the 1976 value assigned to the BO-2 wall storage tanks was probably the BO-l wall storage tank value. 
TABLE 14

ROOM 124 PROCESSING, SINTERING, GRINDING

Grams Plutonium

\begin{tabular}{|c|c|c|c|}
\hline & & $\begin{array}{c}1976 \\
\text { Inventory } \\
\end{array}$ & $\begin{array}{c}\text { Final } \\
\text { Measurement }\end{array}$ \\
\hline $\begin{array}{l}\text { Box 11B } \\
\text { Box l1B Filter }\end{array}$ & Pressing \& Granulator & $\begin{array}{r}382 \\
10\end{array}$ & $\begin{array}{r}332 \\
-\end{array}$ \\
\hline $\begin{array}{l}\text { Calciner } \\
\text { Tunnel }\end{array}$ & & $\begin{array}{l}65 \\
36\end{array}$ & 35 \\
\hline Box IIA & Slugging & 557 & 355 \\
\hline Filter Box IIA & & 8 & $=$ \\
\hline $\begin{array}{ll}\text { Box } 12 \\
\text { Box } 14 \mathrm{~A}\end{array}$ & $\begin{array}{l}\text { Tunnel } \\
\text { Sintering Furnace } \\
\text { Inlet }\end{array}$ & $\begin{array}{r}39 \\
109\end{array}$ & $\begin{array}{r}15 \\
147\end{array}$ \\
\hline Box 14B & $\begin{array}{l}\text { Sintering Furnace } \\
\text { Outlet }\end{array}$ & 43 & 85 \\
\hline Box $15 \mathrm{C}$ & Centerless Grinder & 283 & 224 \\
\hline Box $15 \mathrm{C}$ Filter & $\cdot$ & 7 & - \\
\hline BOX $15 \mathrm{~B}$ & Outgas Furnace Inlet & 50 & 14 \\
\hline Box 15B Filter & & 1 & - \\
\hline Box 15A & Outgas Furnace Outlet & 5 & 11 \\
\hline Box 15A Filter & & 0 & 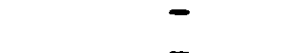 \\
\hline Box 16 & Outgas Furnace & 9 & $\overline{-}$ \\
\hline Box 13A & Calciner Exit & 2 & 3 \\
\hline Box 13B & Calciner entrance & 4 & - \\
\hline Int. Filter & & 4 & 17 \\
\hline Duct & & 127 & 82 \\
\hline $\begin{array}{l}\text { Powder Carts } \\
\text { Harper Furance }\end{array}$ & & $\begin{array}{r}51 \\
203\end{array}$ & $\begin{array}{r}55 \\
150\end{array}$ \\
\hline Not Assigned & & $=$ & 7 \\
\hline TOTAL ROOM 124 & & 1,995 & 1,532 \\
\hline LIMIT-OF-ERROR & & \pm 549 & \pm 195 \\
\hline NUMBER OF PACKAGES & MEASURED & & 3,161 \\
\hline
\end{tabular}

The significant increase in the intermediate filter from the 4 grams to 17 grams is attributed to movement of materials during the cut-up operations. 
TABLE 15

ROOM 123 ROD LOADING AND WELDING

Grams PIutonium

1976

Final

Inventory

Measurement

\author{
Box 17 \\ Box 18 \\ Box 18 Filter \\ Duct \\ TOTAL ROOM 123 \\ Tunnel room \\ Stack Make-Up \\ LIMIT-OF-ERROR \\ NUMBER OF PACKAGES MEASURED
}

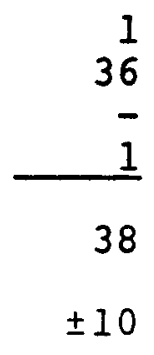

19

$\pm 10$

$\pm 8$

151 
TABLE 16

ROOM 116 MAINTENANCE

Grams Plutonium

-

1976

Einal

Inventory Measurement

Box 45

Box 45 Filter.

TOTAL ROOM 116

Maintenance Glovebox

18

16

LIMIT-OF-ERROR.

18

16

$\pm 5$

$\pm 28$

NUMBER OF PACKAGES MEASURED

230 
TABLE 17

ROOM 127 SCRAP PROCESSING

Grams Plutonium

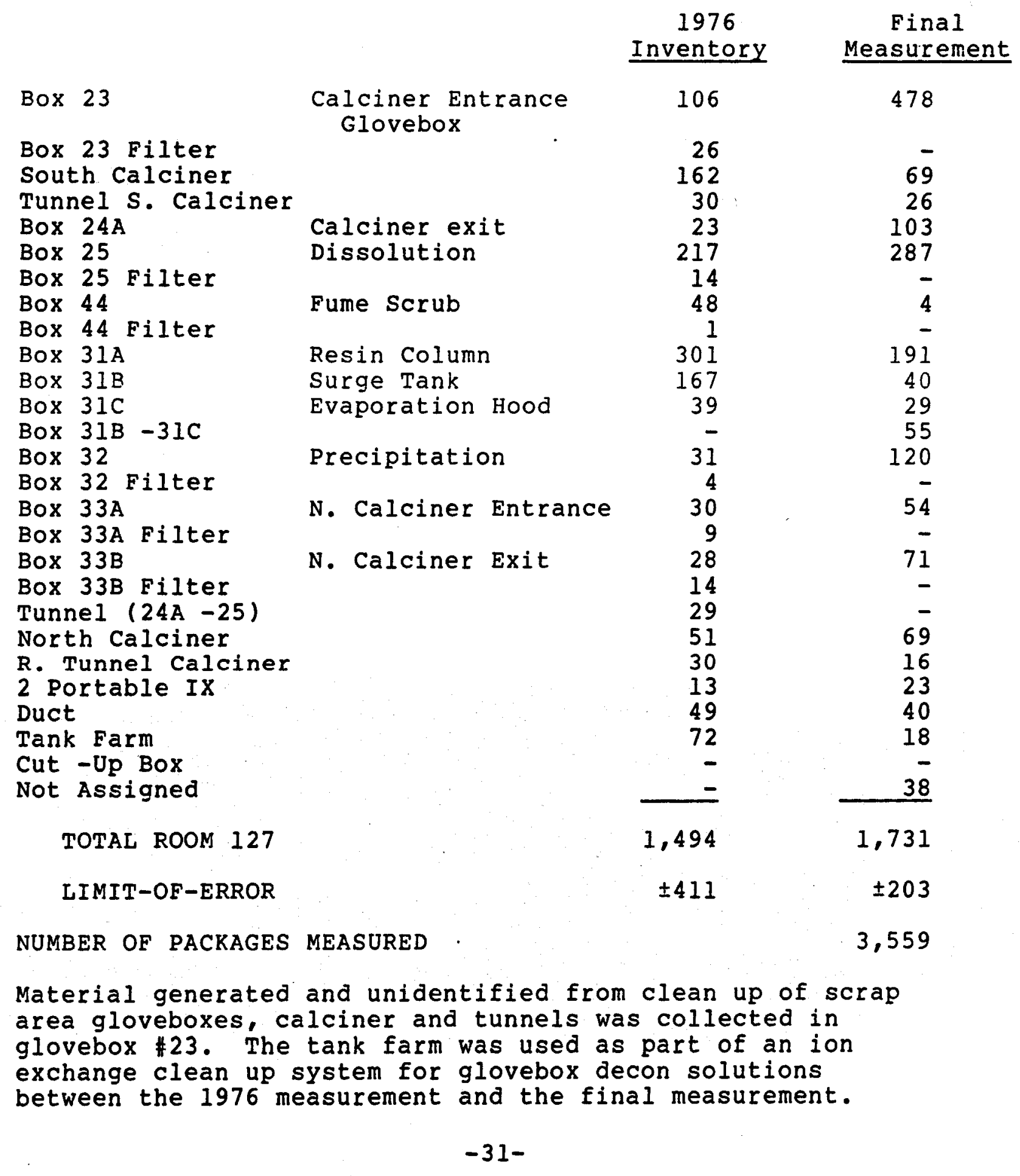


TABLE 18

ROOM BO-I SCRAP TREATMENT

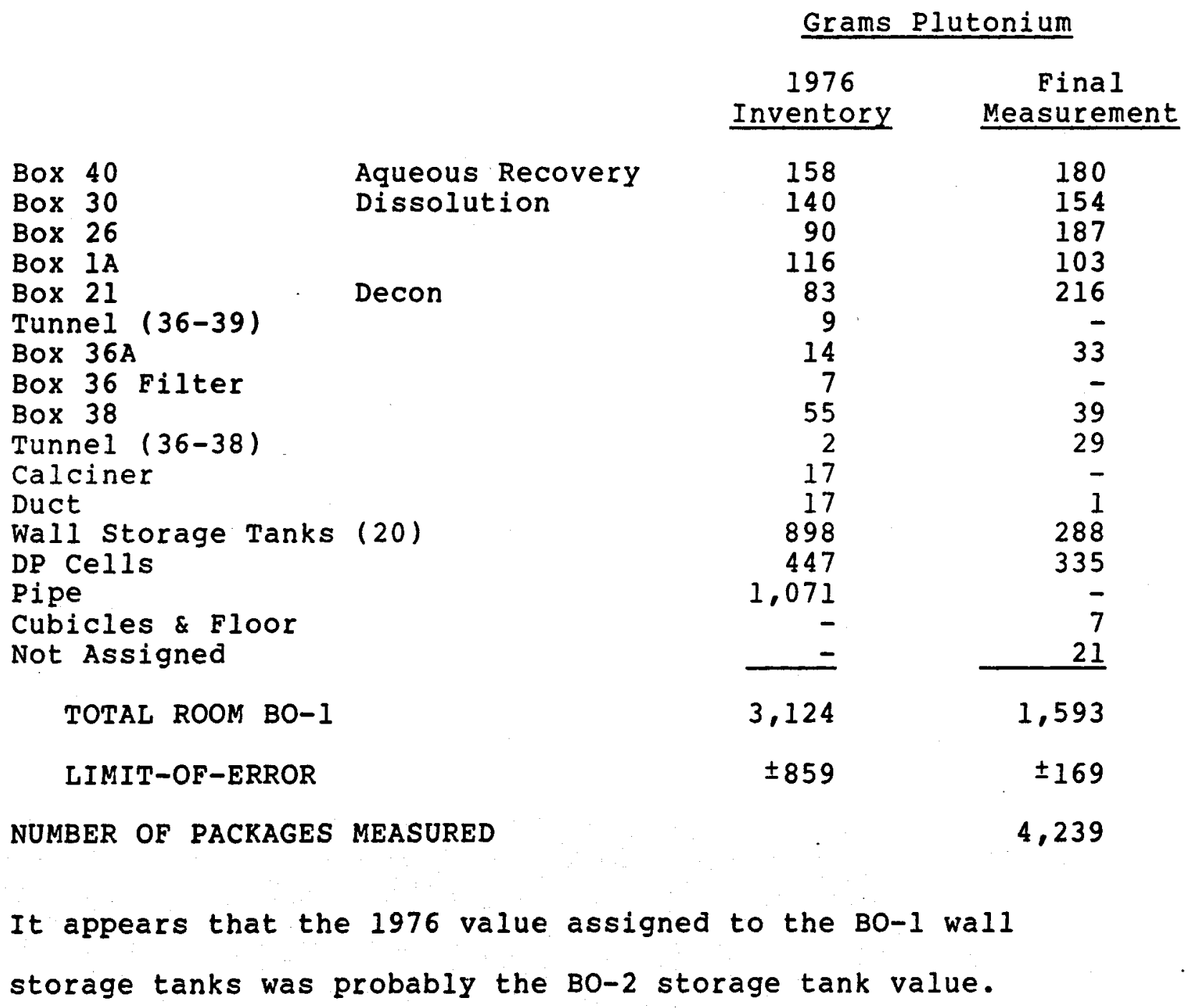


TABLE 19

ROOM BO-5 SOLVENT EXTRACTION

Grams Plutonium

1976 Final

Inventory Measurement

Box 27A

1,592

1,274

LIMIT-OF-ERROR

$\pm 438$

$\pm 144$

NUMBER OF PACKAGES MEASURED

4,044 
TABLE 20

\section{LABORATORY}

\begin{tabular}{cc}
$\frac{\text { Grams Plutonium }}{1976}$ & $\begin{array}{c}\text { Final } \\
\text { Inventory }\end{array}$ \\
\hline- & 57 \\
& \pm 28 \\
& 1,917
\end{tabular}


TABLE 21

\section{SUMMARY - ALL INVENTORY}

Grams Plutonium

\section{Room \#}

128 Coprecipitation \& Oxide

BO-2 Solution Storage \&

Blending

124 Pressing \& sintering

123 Rod Loading

116. Maintenance

BO-1 Scrap Treatment

127 Scrap Processing

BO-5 Solvent Extraction

Laboratory

LIMIT-OF-ERROR

NUMBER OF PACKAGES MEASURED
Final

Inventory Measurement Difference

861

1,696

1,995

38

18

3,124

1,494

1,592

$\frac{-}{10,818}$

$\pm 2,975$
128

(557)

463

17

2

1,531

(237)

318

(57)

1,608

$\pm 72$

28,357 


\subsection{AUDIT TEAM}

\subsection{GENERAL}

SFC's Cimarron Facility was the first fuel cycle facility to apply non-destructive assay methods for measurement of hold-up of plutonium in a processing plant. The measurements performed by the audit team were also a first NDA audit of a private firm by a government agency.

Because its purpose was independent measurement, the audit team could make no assumptions concerning the location of the plutonium either within a room or a glovebox. - When coupled with the need for precise measurements sufficient to allow a meaningful comparison of results, the audit team was required to perform many more measurements on some significant items than were performed by SFC for its inventory.

The techniques, instrumentation, results obtained and a discussion of start-up and operational problems 
encountered by the audit team were provided to the NRC in a document entitled Measurement of Plutonium in Processing Equipment at Kerr-McGee Plutonium Fuel Fabrication Facility, May 28, 1976.

The audit team's strategy was to make careful measurements on the equipment expected to have the most significant plutonium hold-up and to supplement those measurements with semi-quantitative surveys of the entire process equipment to insure that no significant hold-up quantities had been missed. The strategy included the following considerations:

- The measurements of equipment would be very carefully made and with sufficient precision to permit meaningful comparisons with SFC's values for the same items.

- The measurements would be sufficiently extensive to encompass the great majority of the retained plutonium, thereby permitting a confident extrapolation of measured results into a total plant hold-up. 
The bulk of the quantitative assay work was carried out using an Eberline Stabilized Assay Meter (SAM), a self-contained high-voltage supply, an amplifier, a single channel analyzer and a scaler, which were coupled to a NaI(TI) - photomultiplier detector sensitive to the characteristic gamma radiations from plutonium. The surveys were performed using a handheld NaI(T1) detector-ratemeter instrument.

In those cases where the gamma-ray attenuation was so high as to make corrections unreliable, a semidirectional neutron detector was used to take advantage of the increased penetrability of the neutrons from plutonium.

A new concept in hold-up measurements was tried on an experimental basis for the first time. A nondirectional neutron detector was used in an attempt to assay the total hold-up in a given room, without the detailed and laborious measurements and calculations required by the gamma measurements. 
A new type of gamma ray detector, a cadmium telluride (CdTe) diode, was also used experimentally for the first time as a survey instrument for the special case of hold-up in pipes.

\subsection{ITEMS MEASURED}

Initially, the entire process area of the plant was surveyed using a lead shielded $2.5 \mathrm{~cm}$ by $2.5 \mathrm{~cm}$ NaI(TI) gamma ray detector attached to a ratemeter. This preliminary scan permitted the identification of "hot spots" (i.e., places where higher concentrations of plutonium appeared to be located). In the remaining time, the audit team measured gloveboxes, pipes, and tanks identified in the preliminary survey as having measurable quantities of plutonium.

Time limitations prevented the quantitative measurement of every pipe, filter, and glovebox in the plant. It was therefore necessary to extrapolate from the measured quantities to obtain an estimated value for the entire facility. This extrapolation 
was guided by the results of the early preliminary gamma ray scan and was confirmed by the overall neutron survey made with the large detector.

Table 22 shows the audit team's measured quantities of plutonium and the extrapolated values for different broad categories of equipment. Twenty gloveboxes were not directly measured. From the results of the preliminary gamma ray scan and quantitative results for gloveboxes with small amounts of material, the unmeasured gloveboxes were estimated to contain between zero and 50 grams of plutonium. The "estimate" value was obtained by assuming 30 grams per glovebox not measured and the "upper" and "lower limits" by assuming 50 grams per box and zero grams per box, respectively.

A similar exercise was followed to obtain values for plutonium in the pipes. After the pipes identified as having the largest residual plutonium were measured, an average pipe residue of $3.3 \times 10^{-3}$ $\mathrm{gm} / \mathrm{cm}$ was estimated for the remaining pipes, then multiplied by the approximately $10^{5} \mathrm{~cm}$ length of pipe that was still unmeasured. 
The measured filters and ducts proved to have relatively little plutonium in them; thus the results of this extrapolation do not significantly affect the plant total.

An extrapolated value for the wall storage tanks embedded in $4^{\prime}$ thick, heavily reinforced concrete walls was obtained by comparing these tanks with tanks in the plant that had held similar solutions. The 40 wall tanks in room $B O-2$ are similar to the weigh tanks in Box 4 which averaged 10 grams per tank. The 20 wall tanks in Room BO-l do not have an obvious measurable counterpart; however, no measured tanks of that size exceeded 17 grams per tank. Allowing for a possible higher hold-up in these tanks, an average value of 30 grams per tank was assigned. The lower and upper limits were obtained by assuming values equal to one-half and twice the estimated values.

The gauges not assayed by the audit team were measured by SFC subsequent to the inventory and were accepted by the audit team, given the good agreement on other measurements. 
TABLE 22

AUDIT TEAM RESULTS

TOTAL PLANT PLUTONIUM HOLD-UP

\begin{tabular}{|c|c|c|c|}
\hline & \multicolumn{3}{|c|}{ GRAMS } \\
\hline$y$ & ESTIMATE & $\begin{array}{l}\text { LOWER } \\
\text { LIMIT }\end{array}$ & $\begin{array}{l}\text { UPPER } \\
\text { LIMIT } \\
\end{array}$ \\
\hline $\begin{array}{l}\text { Gloveboxes Measured } \\
\text { Gloveboxes Not Measured }\end{array}$ & $\begin{array}{r}4.650 \\
600 \\
\end{array}$ & $\begin{array}{r}3,000 \\
- \\
\end{array}$ & $\begin{array}{l}6,590 \\
1,000 \\
\end{array}$ \\
\hline TOTAL GLOVEBOXES & 5,250 & 3,000 & 7,590 \\
\hline $\begin{array}{l}\text { Pipes Measured } \\
\text { Pipes Not Measured }\end{array}$ & $\begin{array}{l}630 \\
330 \\
\end{array}$ & $\begin{array}{l}475 \\
175 \\
\end{array}$ & $\begin{array}{l}790 \\
600 \\
\end{array}$ \\
\hline & 960 & 650 & 1,390 \\
\hline $\begin{array}{l}\text { Filters Measured } \\
\text { Filters Not Measured }\end{array}$ & $\begin{array}{l}30 \\
50 \\
\end{array}$ & $\begin{array}{l}15 \\
15 \\
\end{array}$ & $\begin{array}{r}60 \\
100 \\
\end{array}$ \\
\hline & 80 & 30 & 160 \\
\hline $\begin{array}{l}\text { Wall Tanks } \\
\text { (Not Measured) } \\
\text { Gauges (Not Measured) }\end{array}$ & $\begin{array}{r}1,000 \\
670 \\
\end{array}$ & $\begin{array}{l}500 \\
670 \\
\end{array}$ & $\begin{array}{r}2,000 \\
670 \\
\end{array}$ \\
\hline TOTAL INVENT & 7,960 & 4,850 & 11,810 \\
\hline
\end{tabular}




\subsection{COMPARISON OF MEASUREMENT DATA}

\subsection{GENERAL OBSERVATION}

As noted previously, three sets of measurements were taken on the plutonium hold-up in the process equipment at the cimarron Facility. SFC performed the first non-destructive assay measurement in early 1976, followed by the NRC's NDA. The third measurement occurred during the final packaging of plant equipment as it was loaded as small cut-up pieces into drums for shipment to an off-site disposal area.

The data from these sets of measurements are in Tables 23 through 31. In evaluating these data, several considerations are important to note:

First, SFC's 1976 procedure resulted from several years of testing, calibrations and experience and involved a significant number of repetitive measurements. Due to time constraints and other reasons, the audit team's 1976 measurements were less extensive and greater reliance was placed on extrapolation of measured data to unmeasured equipment. 
Second, SFC's final inventory measurements were conducted on much smaller and relatively standardized packages, which yielded a much smaller limit-of-error.

Third, in order to reduce the potential of airborne contamination, decon solutions were used on the gloveboxes prior to cut up and the plutonium in the decon solutions lost identity when the decon solutions were cleaned by ion exchange.

In summary, the above observation is provided to emphasize that the significant data shown in the attached tables are room totals - as opposed to specific glovebox or equipment measurements. 
TABLE 23

ROOM 128 COPRECIPITATION AND OXIDE PRODUCTION

\begin{tabular}{|c|c|c|}
\hline $\begin{array}{c}1976 \\
\text { INVENTORY }\end{array}$ & $\begin{array}{c}\text { FINAL } \\
\text { MEASUREMENT }\end{array}$ & $\begin{array}{l}\text { AUDIT } \\
\text { TEAM } \\
\end{array}$ \\
\hline 241 & 153 & 113 \\
\hline 5 & - & - \\
\hline 4 & - & - \\
\hline 21 & 62 & - \\
\hline 5 & 4 & - \\
\hline $\begin{array}{r}4 \\
27\end{array}$ & 25 & $\bar{n}$ \\
\hline $\begin{array}{r}37 \\
146\end{array}$ & $\begin{array}{r}18 \\
157\end{array}$ & $\begin{array}{r}60 \\
-\end{array}$ \\
\hline 3 & - & - \\
\hline 78 & 25 & - \\
\hline 2 & - & - \\
\hline $17 \overline{6}$ & 161 & 122 \\
\hline 32 & 29 & - \\
\hline 28 & 23 & - \\
\hline- & 2 & - \\
\hline 79 & 40 & - \\
\hline- & - & - \\
\hline- & - & - \\
\hline- & 1 & $=$ \\
\hline \multirow[t]{2}{*}{861} & 700 & 295 \\
\hline & 33 & 410 \\
\hline 861 & 733 & 705 \\
\hline \pm 237 & \pm 135 & $\begin{array}{l}360 \\
+250\end{array}$ \\
\hline
\end{tabular}

Room 128 was difficult to measure by NDA techniques because of the large size of the gloveboxes within the room, the influence of the wall storage tanks in the wall adjacent to the room, and the density of equipment within each glovebox. Of note is that the audit team's extrapolated values for gloveboxes and pipes not measured were within only a few grams of Kerr-McGee's measured values. 
TABLE 24

ROOM BO-2 SOLUTION STORAGE AND BLENDING

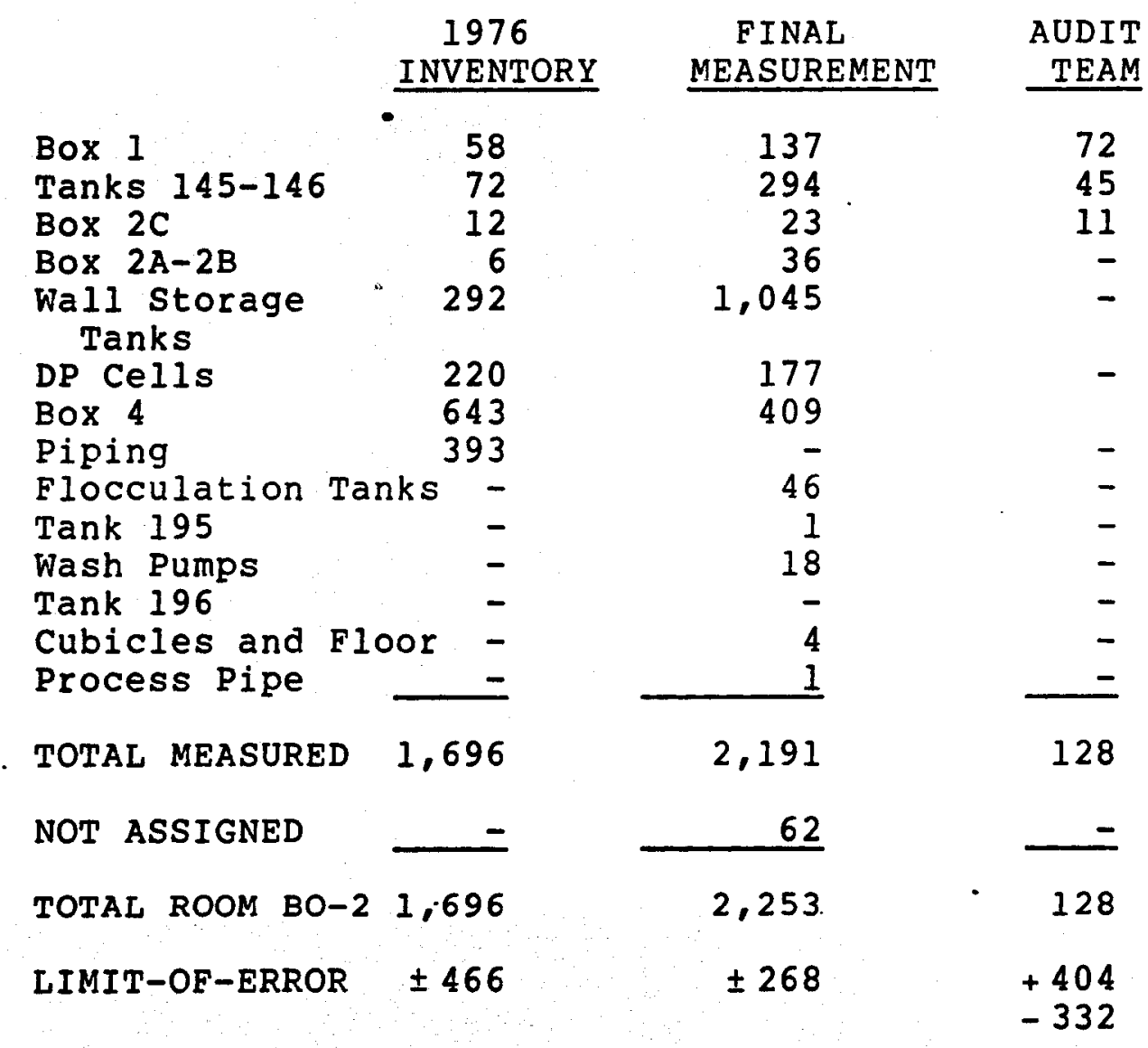

Several anomalies should be noted. First, flushing of tanks 145-146 was not as effective as had been anticipated. These tanks contained boron raschig rings which apparently masked the radiation. Second, Box 1 was primarily a series of pumps, valves, and a manifold which would be difficult to NDA under any circumstances. The primary difference between the two Kerr-McGee inventories was the apparent mislabeling of the wall storage tank hold-up data as noted earlier. 
TABLE 25

ROOM 124 PROCESSING, SINTERING, GRINDING

\begin{tabular}{|c|c|c|}
\hline $\begin{array}{c}1976 \\
\text { INVENTORY } \\
\end{array}$ & $\begin{array}{c}\text { FINAL } \\
\text { MEASUREMENT }\end{array}$ & $\begin{array}{r}\text { AUDIT } \\
\text { TEAM } \\
\end{array}$ \\
\hline 382 & 332 & 333 \\
\hline 10 & - & \\
\hline 65 & 35 & 249 \\
\hline 36 & $\bar{z}$ & \\
\hline 557 & 355 & 236 \\
\hline $\begin{array}{r}8 \\
39\end{array}$ & $=$ & - \\
\hline $\begin{array}{r}39 \\
109\end{array}$ & $\begin{array}{r}15 \\
147\end{array}$ & $\overline{-}$ \\
\hline 43 & 85 & - \\
\hline 283 & 224 & 123 \\
\hline 7 & - & \\
\hline 50 & 14 & - \\
\hline 1 & - & - \\
\hline 5 & 11 & - \\
\hline$\overline{0}$ & - & 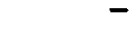 \\
\hline 2 & 3 & - \\
\hline 4 & - & - \\
\hline 4 & 17 & - \\
\hline 127 & 82 & $\overline{-}$ \\
\hline $\begin{array}{r}51 \\
203 \\
\end{array}$ & $\begin{array}{r}55 \\
150 \\
\end{array}$ & $\begin{array}{r}1 \\
451 \\
\end{array}$ \\
\hline 1,995 & 1,525 & 1,393 \\
\hline$=$ & 7 & 2 \\
\hline 1,995 & 1,532 & 1,395 \\
\hline \pm 549 & \pm 195 & $\begin{array}{l}+435 \\
-595\end{array}$ \\
\hline
\end{tabular}

Several obvious differences exist in the individual item data shown for Room 124. The SFC data are fairly close between inventories. An explanation for the individual differences in the audit team's results is not readily apparent; however, the overall room total is in reasonable agreement.

$$
-47-
$$


TABLE 26

\section{ROOM 123 ROD LOADING AND WELDING}

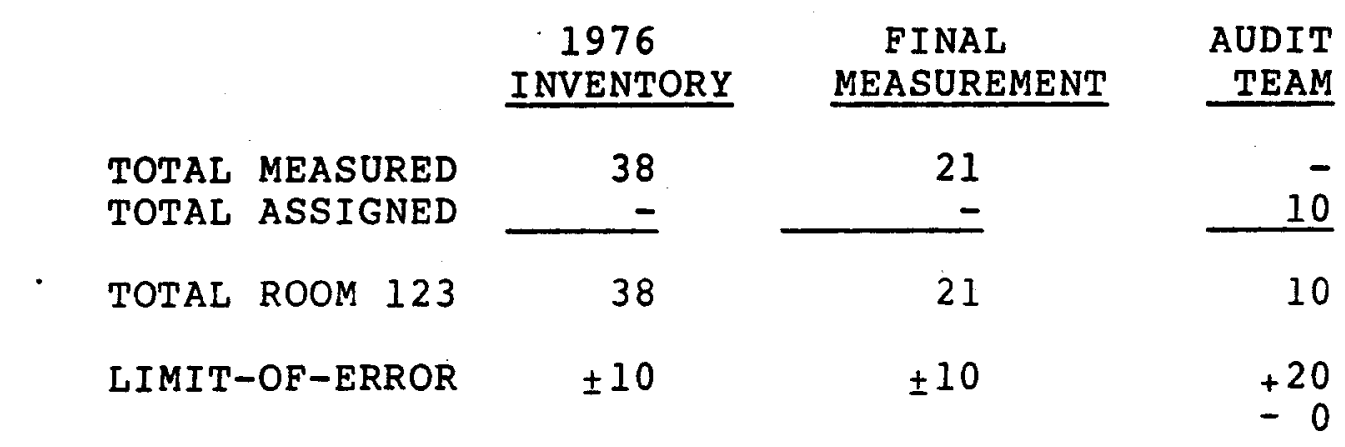

The audit team did not survey Room 123 . 
TABLE 27

ROOM 116 MAINTENANCE

\begin{tabular}{lcccc} 
& $\begin{array}{c}1976 \\
\text { INVENTORY }\end{array}$ & $\begin{array}{c}\text { FINAL } \\
\text { MEASUREMENT }\end{array}$ & $\begin{array}{c}\text { AUDIT } \\
\text { TEAM }\end{array}$ \\
\cline { 2 - 4 } TOTAL MEASURED & 18 & - & 16 & - \\
TOTAL ASSIGNED & $\frac{-}{18}$ & - & - \\
TOTAL ROOM 116 & & - & - \\
LIMIT-OF-ERROR & \pm 5 & & - \\
& &
\end{tabular}


TABLE 28

ROOM 127 SCRAP PROCESSING

1976
INVENTORY

FINAL

AUDIT

MEASUREMENT

TEAM

Box 23

Box 23 Filter

South Calciner

Tunnel

Box 24A

Box 25

Box 25 Filter

Box 44

Box 44 Filter

Box $31 A$

Box 31B

Box 31C

Box 31B \& 31C

Box 32

Box 32 Filter

Box 33A

Box 33A Filter

Box 33B

Box 33B Filter

Tunnel (24A-25)

North Calciner

R. Tunnel Calciner

2 Portable IX

Duct

Tank Farm

Cut-Up Box

TOTAL MEASURED

NOT ASSIGNED

TOTAL ROOM $127 \quad 1,494$

LIMIT-OF-ERROR \pm 411

\section{6}

26

162

30

23

217

14

48

301

167

39

$\overline{3 i}$

31

30

9

28

14

29

51

30

13

49

72

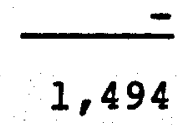

$=$

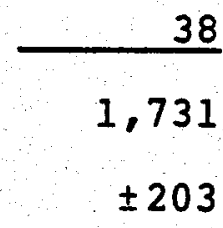

478

$6 \overline{9}$

26

103

287

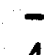

191

40

29

55

120

$5 \overline{4}$

$-$

71

$-$

$-$

69

16

23

40

18

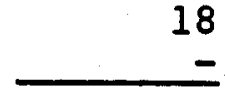

1,693

38
4

150

$1,214^{\circ}$

$+455$

$-450$

Given the number and size of gloveboxes in this room, the correlation of the data among the three independent inventories is remarkable. The major difference was in Box 23 where 478 grams of plutonium were measured in the final decommissioning inventory, and only 106 grams were measured in the 1976 NDA inventory. Material generated and unidentified from cleanup of scrap area gloveboxes, calciner and tunnels was collected in glovebox \#23.

$$
-50-
$$


TARLE 29

ROOM BO-1 SCRAP TREATMENT

\begin{tabular}{|c|c|c|c|}
\hline & $\begin{array}{c}1976 \\
\text { INVENTORY } \\
\end{array}$ & $\begin{array}{c}\text { FINAL } \\
\text { MEASUREMENT }\end{array}$ & $\begin{array}{l}\text { AUDIT } \\
\text { TEAM } \\
\end{array}$ \\
\hline Box 40 & 158 & 180 & 18 \\
\hline Box 39 & 140 & 154 & 68 \\
\hline Box 26 & 90 & 187 & \\
\hline & 116 & 103 & 141 \\
\hline Box 21 & 83 & 216 & 59 \\
\hline Tunnel $(36-39)$ & 9 & - & \\
\hline BOX $36 \mathrm{~A}$ & 14 & 33 & 10 \\
\hline Box 36 Filter & 7 & - & \\
\hline Box 38 & 55 & 39 & 1 \\
\hline Tunnel $(36-38)$ & 2 & 29 & \\
\hline Calciner. & 17 & - & 26 \\
\hline Duct & 17 & 1 & \\
\hline Wall storage Tar & ks 898 & 288 & \\
\hline DP Cells & 447 & 335 & \\
\hline $\begin{array}{l}\text { Pipe } \\
\text { Cubicles \& Floor }\end{array}$ & 1,071 & $\overline{7}$ & \\
\hline TOTAL MEASURED & 3,124 & 1,572 & 339 \\
\hline NOT ASSIGNED & $=$ & 21 & 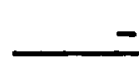 \\
\hline TOTAL ROOM BO-1 & 3,124 & 1,593 & 339 \\
\hline LIMIT-OF-ERROR & \pm 859 & \pm 169 & $\begin{array}{l}+261 \\
-94\end{array}$ \\
\hline
\end{tabular}

The apparent mislabeling of the wall tank recordings contributes significantly to the difference between the two Kerr-McGee inventory results. The apparent discrepancy in the audit team's results cannot be reasonably explained; however, for those items measured by the audit team, a close overall correlation with those items measured by Kerr-McGee in 1976 is shown. 
TABLE 30

ROOM BO-5 SOLVENT EXTRACTION

\begin{tabular}{|c|c|c|c|}
\hline & $\begin{array}{c}1976 \\
\text { INVENTORY } \\
\end{array}$ & $\begin{array}{c}\text { FINAL } \\
\text { MEASUREMENT } \\
\end{array}$ & $\begin{array}{l}\text { AUDIT } \\
\text { TEAM } \\
\end{array}$ \\
\hline Box $27 A$ & 1,592 & 1,274 & 850 \\
\hline IMIT-OF-ERROR & \pm 438 & \pm 144 & $\begin{array}{l}+404 \\
-332\end{array}$ \\
\hline
\end{tabular}


TABLE 31

SUMMARY - ALL INVENTORY

\begin{tabular}{ccc}
1976 & FINAL & AUDIT \\
INVENTORY & MEASUREMENT & TEAM \\
\hline
\end{tabular}

MEASURED

Room - 128

RoOm - BO-2

861

Room - 124

1,696

Room - 123

1,995

Room - 116

38

Room - 127

18

RoOm - BO-1

1,494

RoOm - BO-5

3,124

Laboratory

1,592

$-$

700

2,191

1,525

21

16

1,693

1,572

1,274

Pipes Measured

Filters Measured

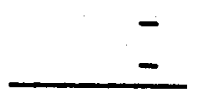

57

TOTAL MEASURED

10,818

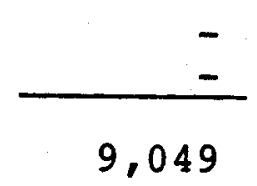

295

128

1,393

$1,06 \overline{4}$

339

850

$-$

630

30

4,729

\section{ASSIGNED}

RoOm - 128
RoOm - BO-2
RoOm - 124
RoOm - 123
RoOm - 116
RoOm - 127
RoOm - BO-1
RoOm - BO-5

Gloveboxes Not Measured Pipes Not Measured

Filters Not Measured

Wall Tanks Not Measured

Gauges Not Measured

TOTAL ASSIGNED

TOTAL

$\begin{array}{rrr}- & 33 & 410 \\ - & 62 & - \\ - & 7 & 2 \\ - & - & 10 \\ - & - & - \\ - & 21 & 150 \\ - & - & - \\ - & - & 600 \\ - & - & 330 \\ - & - & 50 \\ - & - & 1,000 \\ - & 161 & 670 \\ 10,818 & 9,210 & 3,222 \\ & & 7,951\end{array}$




\subsection{SUMMARY AND CONCLUSIONS}

\subsection{SUMMARY}

Table 32 summarizes the key data from the three independent inventory measurements. Notably, the final inventory measurements fall within the upper and lower confidence levels of both 1976 in-place measurements.

The data suggest several methods and various pieces of equipment not specifically designed for that purpose can be useful tools to measure hold-up in process equipment. Additionally, the data suggest that a program involving repetitive measurements over a period of time would develop a higher level of confidence in the results.

Given the state of the art in 1976 and the difficulty of conducting an in-place measurement program within a plant not specifically designed to accommodate in-place measurements for inventory purposes, the techniques developed by Sequoyah Fuels and the audit team produced remarkably comparable results. 
An acceptable limit of error can be achieved for determining plant hold-up for inventory purposes with in-place NDA measurements. 
TABLE 32

IMITINL M NDA

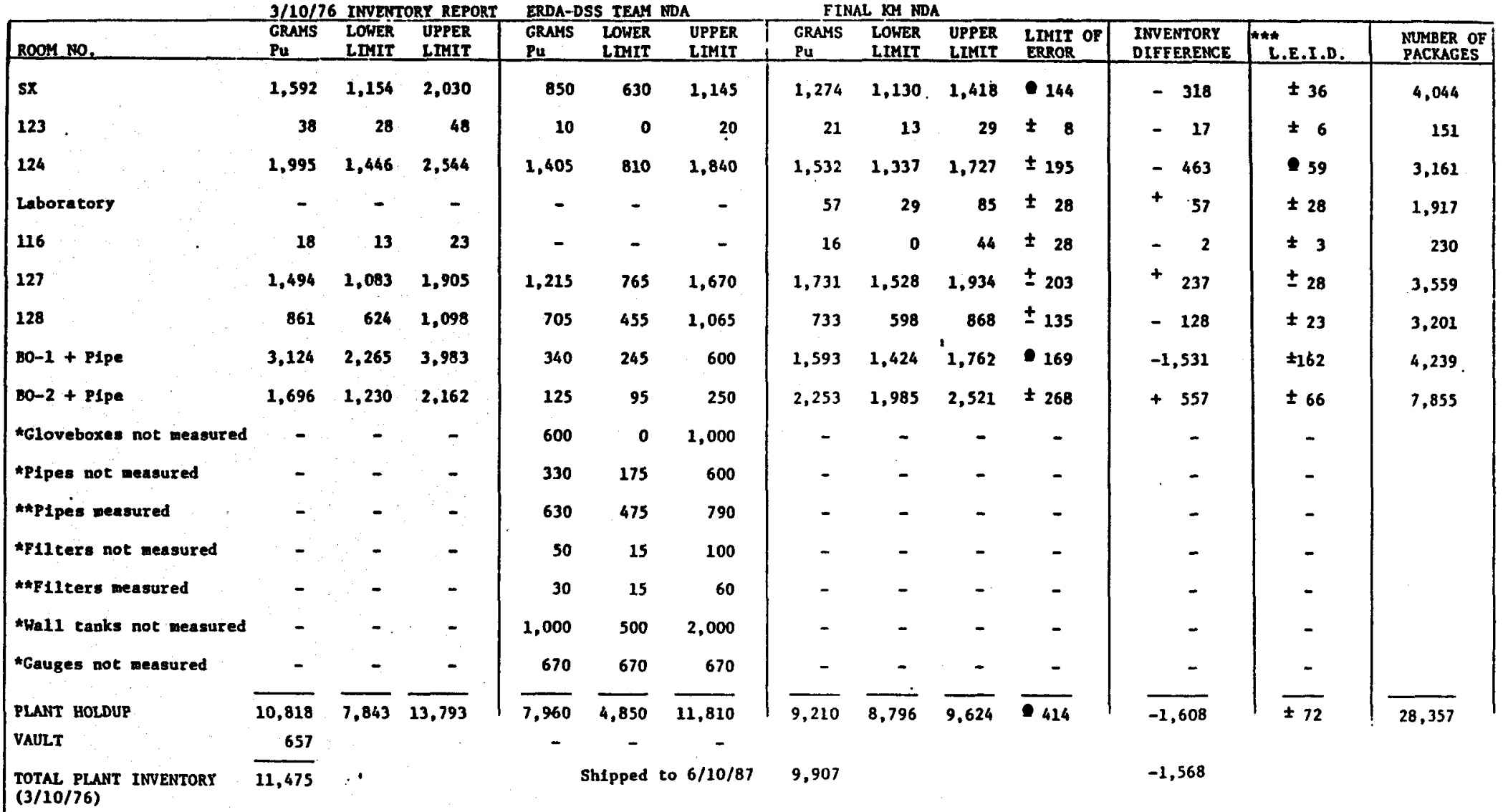

* Extrapolated Es:timate by ERDA-DSS Team

* Measured by ERDA-DSS Team but not Identified by room location

**ALImit of Error of Inventory Difference

The final NDA total of 9,210 grams removed from the Pu-plant does not Include an estimated 4 grams of Pu in low level waste that will be produced by the decontasination work remaining to be completed.
The discrepancy between the Plant Holdup Inventory Difference of -1608 grans and the difference of -1563 grams from comparing the
$3 / 10 / 76$ inventory to the shipment records 1 do due to repackaging and NDA of the material that was in the vault on $3 / 10 / 76$. 